\title{
COST-BENEFIT ANALYSIS OF PV GENERATORS AT RESIDENTIAL BUILDINGS IN THE REGION OF RUSE, BULGARIA
}

\author{
Katerina Georgieva Gabrovska-Evstatieva* \\ Ruse university "Angel Kanchev", Bulgaria \\ Boris Ivanov Evstatiev \\ Ruse university "Angel Kanchev", Bulgaria
}

In this study a method for cost-benefit analysis of investments in PV generators at residential buildings has been presented. The benefits are evaluated in two categories: financial benefits in terms of net present value of the money and the return on the investment; the ecological benefits presented in saved $\mathrm{CO} 2$ emissions in tons and in percentages. A cost-benefit analysis of a PV investment at an apartment in the city of Ruse is presented with different scenarios in terms of installed power. Two risk factors are also evaluated - the buying price of PV energy and the selling price of conventional energy. The obtained results showed that the investment could payback for 6 to 9 years, if the installation is properly sized. The ecological benefits have been evaluated to be approximately $1 t \mathrm{CO}_{2}$ annually or a reduction of $35 \%$ to $42 \%$.

Key words: Cost-benefit analysis, PV generators, Residential buildings

\section{INTRODUCTION}

The constantly increasing prices of energy resources imply the search for reduction of the energy demand and increasing of the energy production. This has led to the creation of a number of stimuli in Bulgaria for using of renewable energy sources (RES), mainly in the form of preferential buying prices of the produced energy. This has led to the creation of an enormous amount of PV plants above $30 \mathrm{kWp}$ but showed as an ineffective approach. Until the last year there were almost no small power plants (under $30 \mathrm{kWp}$ ) connected to the grid, because such procedure was requiring multiple permits and technical projects. In 2016 the Commission for Energy and Water Regulation simplified significantly the procedure which opens new possibilities for application of RES in residential buildings in Bulgaria.

On the other hand during the last years the price of energy from PV sources has been constantly dropping down which is another reason to investigate their payback at resident buildings. According to [09] the advance in the solar technology is expected to reduce the price of the generated PV energy to 4-5 ct/kWh by 2025 and to 2-4 ct/ kWh by 2050 , which would make it competitive even to atomic energy.
Numerous studies have investigated the possibilities to use PV energy sources in residential and public buildings. Nafeh A. E. (2009) explored the electrification of remote households in Egypt using en-tirely PV sources [02]. Kolhe et al. (2002) analysed different combinations of $\mathrm{PV}$ and diesel generators of a school located in India for one life cycle of the PV modules. The study showed that using only PV gen-erators is an acceptable solution if the energy consumption is low [05].

In another study for residential buildings in Malaysia, Elhassan et all. (2012) showed that consid-ering the reduction in the amount of the purchased energy, the payoff time of the investment is 14 years [03]. Ziuku et all. (2012) investigated the period for return on the investment of an integrated PV system in a residential building in South Africa. The results showed that the investment will pay off in 8 years [10]. Manohar et all. (2015) performed a cost-benefit analysis of a solar PV system in Trinidad and Toba-go and the results were unsatisfactory with 32.9 years payback period [06].

The available studies show the investment results from application of PV energy sources vary widely, depending on many factors such as geographical location, application, price of electrical 
energy, buying price of energy from RES, local regulations, etc. The goal of this study is to perform a cost-benefit analysis of an investment in a low power PV plant at a residential building or a small house for the region of Ruse, Bulgaria. The analysis will assess the economic as well as ecological benefits from such invest-ment and will allow to verify its feasibility for the geographical and economic conditions of Bulgaria.

\section{MATERIALS AND METHODS}

\section{Energy production and consumption}

The energy balance of a residential building is:

$$
\mathrm{E}_{\text {cons }}=\mathrm{E}_{\text {conv }}+\mathrm{E}_{\mathrm{pv} \text { (used) }}
$$

where:

$E_{\text {CONS }}$ - is the consumed electrical energy in kWh;

$\mathrm{E}_{\mathrm{CONV}}$ - is the bought energy from conventional sources in $\mathrm{kWh}$;
$E_{P V(U S E D)}$ - the part of PV energy which is used in kWh;

The total produced PV energy is:

$$
\mathrm{E}_{\mathrm{PV}}=\mathrm{E}_{\mathrm{PV}(\mathrm{USED})}+\mathrm{E}_{\mathrm{pV}(\mathrm{EXC})}
$$

where $E_{P V(E X C)}$ is the excess energy.

In this study it is assumed that two streams of information are available:

- The mean hourly energy consumption of the apartment/house for each month of the year $\mathrm{E}_{\mathrm{CONS(t)}}$

- The mean hourly energy production from the PV modules for each month of the year $\mathrm{E}_{\mathrm{PV}(\mathrm{t})^{*}}$.

The block diagram of the algorithm, used to distinguish between used and excess energy from the PV generator is presented in Figure 1.

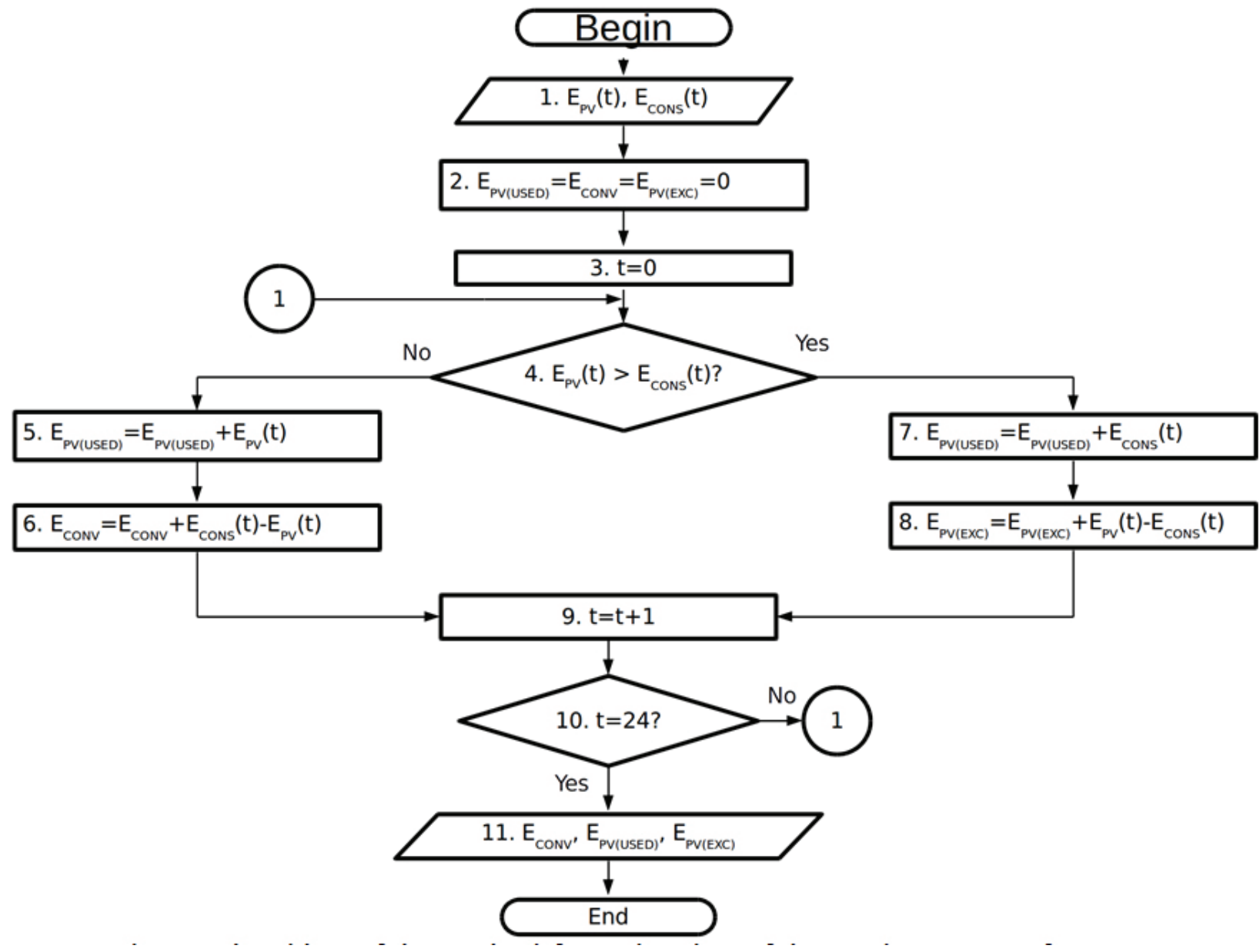

Figure 1: Algorithm of the method for estimation of the used amounts of energy 
In block 2 are initialized the input/output variables and in block 3 - the time variable. If for a cer-tain hour of the day the energy production from the PV generator is lower than the energy consumption, in blocks 5 and 6 the amount of used PV energy and bought conventional energy are updated. Otherwise in blocks 7 and 8 the used PV energy and the excess PV energy are updated. When the last sample (hour of the day) is reached, the algorithm returns the used PV energy $E_{P V(U S E D)}$, the excess $P V$ energy $E_{P V(E X C)}$ and the bought conventional energy $E_{\text {Conv. The }}$ algorithm is also presented in a more generalized form in Figure 2.

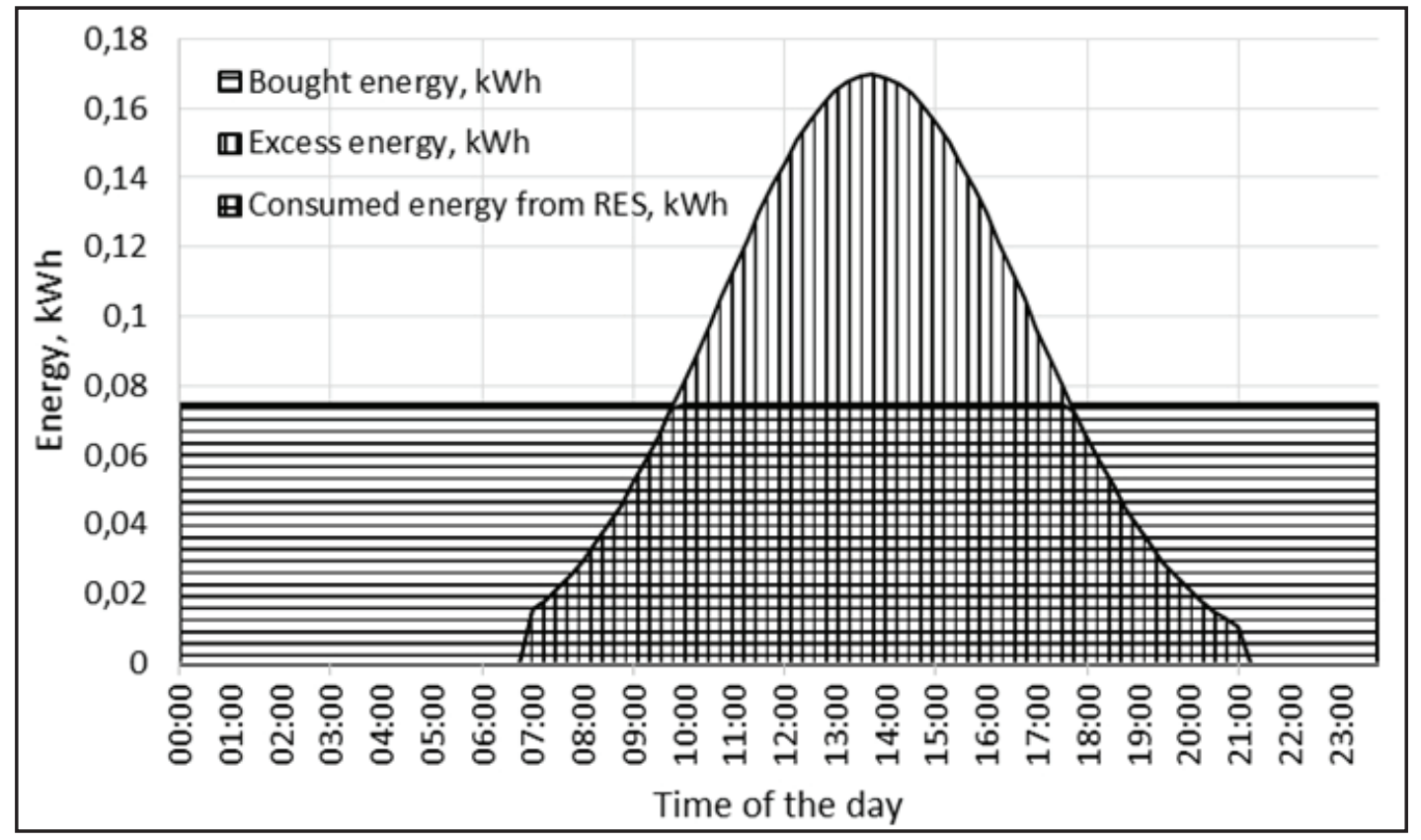

Figure 2: Simplified energy production-consumption model

\section{Investment expenses}

Two types of expenses, related to the investment in PV energy sources, can be distinguished:

- The initial investment;

- The monthly maintenance expenses.

The initial expenses $\mathrm{C}_{\mathrm{INV}}$ are:

$C_{I N V}=C_{P V} \cdot P_{R P}+C_{E Q}, €$

where

$\mathrm{C}_{\mathrm{PV}}$ - is the price for $1 \mathrm{~kW}$ rated power in $€ / \mathrm{kWp}$;

$\mathrm{P}_{\mathrm{RP}}$ - the installed rated power in kWp;

$\mathrm{C}_{\mathrm{EQ}}$ - the additional expenses, related to the investment in $€$.

In this study the monthly maintenance expense $\mathrm{C}_{\mathrm{MN}}$, related to the $\mathrm{PV}$ generator, are estimated with:

$$
C_{M N}=P_{R P} \cdot C_{M N_{0}} € \text {, }
$$

where $\mathrm{C}_{\mathrm{MNO}}$ is the monthly expenses for maintenance of $1 \mathrm{~kW}$ installed $P V$ power in $€ / \mathrm{kWp}$.

\section{Financial benefits from the investment}

In the present study the financial benefits have two components: benefits from not buying con- ven-tional energy and benefits from selling excess energy. The daily financial benefits CFIN. BEN could be ex-pressed with:

$C_{F I N . B E N}=C_{C O N V} \cdot E_{P V(U S E D)}+C_{P V} \cdot E_{P V(E X C)}, €(5)$ where

$\mathrm{C}_{\text {Conv }}$ - is the selling price of energy from conventional sources in $€ / \mathrm{kWh}$;

$\mathrm{C}_{\mathrm{PV}}$ - the buying price of energy from $\mathrm{PV}$ sources in $€ / \mathrm{kWh}$.

Then the daily money flow $\mathrm{C}_{\mathrm{i}(\mathrm{t})}$ for the $\mathrm{i}^{\text {th }}$ day becomes:

$C_{i}(t)=C_{F I N . B E N}^{i}-C_{M N}^{i}, €$

and the net money flow for the $k^{\text {th }}$ month is:

$B_{k}=\sum_{i=0}^{30 / 31} C_{i}(t), €$

The net present value (NPV) of the invested money is estimated with:

$N P V(t)=\sum_{k=1}^{n} \frac{B_{k}(t)}{(1+r)^{n}}-C_{I N V}, €$ 
The cost of capital, $r$ can be obtained with:

$r=\frac{n_{r}-\inf }{1+\inf }$

where $n_{r}$ is the monthly nominal rate of return and inf is the monthly inflation.

Another indicator for the investment is the return on investment (ROI):

$$
R O I=\frac{\sum C_{i}(t)}{C_{I N V}} .100, \%
$$

\section{Other benefits from the investment}

Considering the energy produced by conventional sources leads to significantly higher $\mathrm{CO}_{2}$ emis-sions than from renewable sources, other benefits related to the investment are $\mathrm{CO}_{2}$ emission savings.

The daily emissions of the apartment with a PVhybrid energy supply is:

$$
C O 2_{\mathrm{CONV}+P V}=E_{\mathrm{CONV}} . \mathrm{CO} 2_{0}, \mathrm{~g} \mathrm{CO} 2 \text {, }
$$

where $\mathrm{CO}_{2}$ is the relative emission factor which can be obtained with:

$$
C O 2_{0}=\frac{E_{P V(U S E D)}}{E_{C O N S}} \cdot C O 2_{C O N V+P V}+\frac{E_{C O N V}}{E_{C O N S}} \cdot C O 2_{C O N V}
$$

g CO2/kWh
The potential $\mathrm{CO} 2$ emissions if the PV source was not installed can be estimated with:

$$
C O 2_{\text {POT }}=E_{C O N S} \cdot C O 2_{C O N V}, \mathrm{~g} \mathrm{CO} 2
$$

Then the daily energy savings from the PV investment are:

$$
C O 2_{S A V}=C O 2_{P O T}-C O 2_{P V}, \mathrm{~g} \mathrm{CO} 2
$$

The following coefficient is defined in order to assess the emission savings:

$k_{C O 2_{E C}}=\frac{\sum C O 2_{S A V}}{\sum C O 2_{P O T}} .100, \%$

where $k_{\text {CO2EC }}$ shows the percentile emissions savings as a consequence from the investment.

\section{RESULTS AND DISCUSSION}

\section{Parameters of the study}

The object of the investigation is a four room apartment with PVC windows, insulation and central heating. Its energy consumption for each month of the year is presented in Table 1.

Table 1: Electrical energy consumption of the investigated apartment

\begin{tabular}{||c||c||c|}
\hline \multicolumn{1}{|c||}{ Month } & Monthly energy consumption, kWh & Mean daily energy consumption, kWh \\
\hline \hline January & 265,21 & 8,56 \\
\hline \hline February & 296,11 & 9,87 \\
\hline \hline March & 355,25 & 12,69 \\
\hline \hline April & 312,00 & 10,06 \\
\hline \hline May & 329,75 & 10,99 \\
\hline \hline June & 266,61 & 8,89 \\
\hline \hline July & 288,93 & 9,32 \\
\hline \hline August & 197,82 & 6,38 \\
\hline \hline September & 325,04 & 10,83 \\
\hline \hline October & 317,64 & 10,25 \\
\hline \hline November & 526,96 & 17,57 \\
\hline \hline December & 324,36 & 10,46 \\
\hline \hline
\end{tabular}

Different studies [04,08] have reported similar distributions of the daily household energy consumption, characterized with a minimum during the night and a maximum in the evenings. Ghaemi and Brauner (2009) also reported peaks in the morning during the weekdays and a peak at around 13:00 h dur-ing the weekends [04]. They also created an average normalized load profile to be used for comparison, with three peaks (Figure 3), which is used in the present study. 


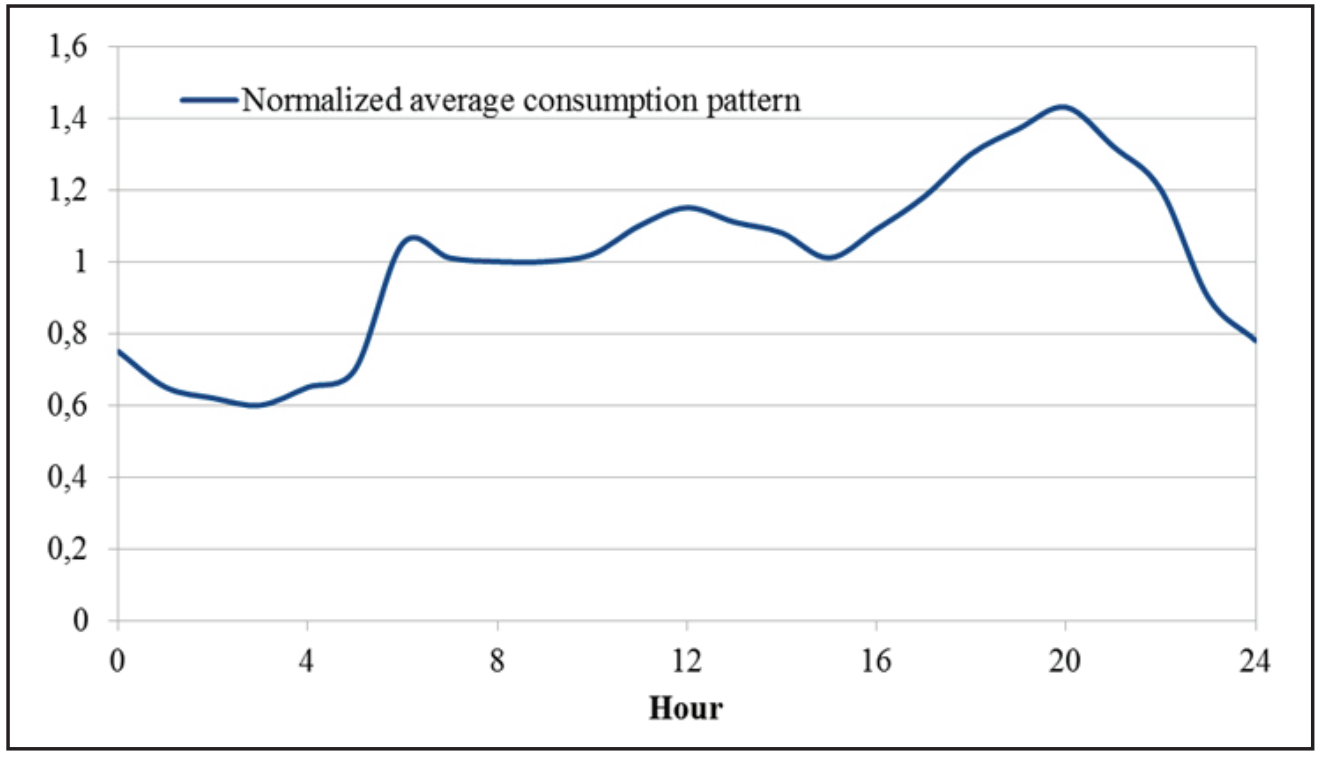

Figure 3: Normalized average household consumption pattern reported in [04]

The hourly energy production from $1 \mathrm{kWp}$ installed PV power in the city of Ruse (Bulgaria) has been used for each month of the year. The data has been acquired from the Zita Ruse PV power plant, the information for which is available in [11]. According to the National Renewable Energy Laboratory the maintenance fee for $\mathrm{PV}$ installations bellow $10 \mathrm{~kW}$ varies between 0 and $40 \$ / \mathrm{kWp}$ [12]. Considering in the present study we investigate low power household installations ( $1 \mathrm{kWp}$ and $2 \mathrm{kWp}$ ), we assume the maintenance fee would be $0 € / \mathrm{kWp}$.

According to the Covenant of Mayors (2010) the emission factor for Bulgaria with and without lifecycle analysis (LCA) is $819 \mathrm{~g} \mathrm{CO} / \mathrm{kWh}$ and 906 g CO2/kWh respectively [01]. The LCA emission factor for PV power plants varies between 20 and $50 \mathrm{~g} \mathrm{CO} 2 / \mathrm{kWh}$. More recent data from the Bulgarian Ministry of the Environment and Water (2014) [07] claims the average emission factor for Bulgaria in 2013 was $616 \mathrm{~g} \mathrm{CO} / \mathrm{kWh}$, however there is no up-to date information on the LCE emission factor. That's why in this study we will increase the standard emission factor with the same ratio as the Covenant of Mayors increase, in order to obtain the LCE emission factor for Bulgaria:

$\mathrm{CO} 2_{\text {CONv }}=616 \times 906 / 819=681 \mathrm{~g} \mathrm{CO} 2 / \mathrm{kWh}$.

Another important parameter is the buying price of PV energy. There was a rapid drop of that price in the recent years from $0.2 € / \mathrm{kWh}$ a couple of years ago to $0.13 € / \mathrm{kWh}$ in 2017. Considering cur-rently in Bulgaria the installed rated PV power is more than the consumption of the country, this price is expected to further drop down. On the other hand the energy consumption worldwide continuously in-creases, it is quite likely the price of conventional energy will increase. For the above reasons two risk factors will be investigated in this study:

- The buying price of the excess energy decreases by $50 \%$ from 0.13 to $0.065 € / \mathrm{kWh}$;

- The conventional energy price increases from 0.14 to $0.20 € / \mathrm{kWh}$.

The other parameters of the performed analysis are presented in Table 2.

Table 2: Other parameters of the cost-benefit analysis.

\begin{tabular}{|l||c||}
\hline Parameter & Value \\
\hline \hline Price for 1 kW installed PV power, $€ / \mathrm{kWp}[13,14]$ & 1500 \\
\hline \hline Life expectancy, years & 25 \\
\hline \hline Price of conventional energy, $€ / \mathrm{kWh}[15]$ & 0.14 \\
\hline \hline LCA emission factor of conventional energy, g CO2/kWh & 681 \\
\hline \hline LCA emission factor of PV generators, g CO2/kWh [01] & 35 \\
\hline \hline Annual nominal rate of return, \% & 1 \\
\hline \hline Annual inflation, \% & 3 \\
\hline
\end{tabular}


Table 3: Scenarios for the cost-benefit analysis

\begin{tabular}{||l||c||}
\hline & Parameters of the scenario \\
\hline \hline Scenario 1 & Installed power: $1 \mathrm{~kW}$, no batteries \\
\hline \hline Scenario 2 & Installed power: $2 \mathrm{~kW}$, no batteries \\
\hline
\end{tabular}

\section{Electrical production and consumption}

The mean values of the electrical production, consumption and the required additional con- ven-tional energy for each month of the year if Scenario 1 and 2 are used are presented in Figure 4 and Figure 5 respectively.

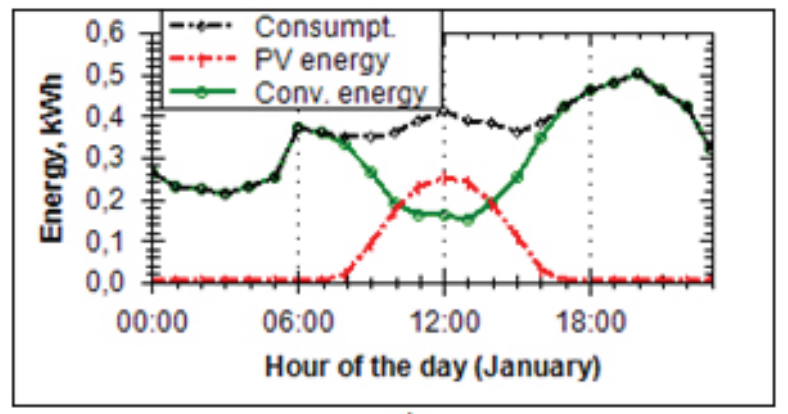

a)

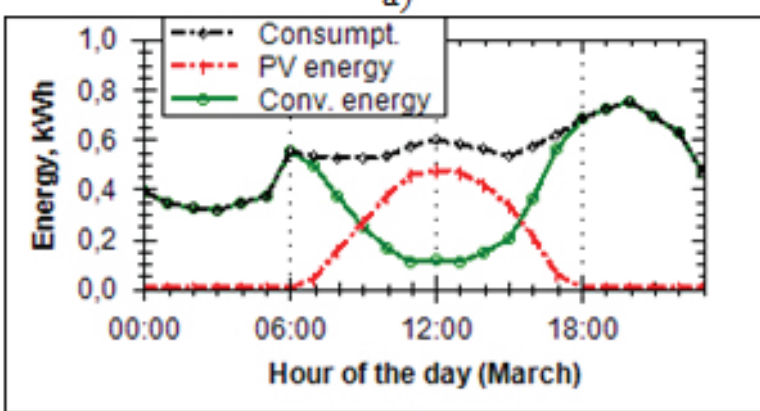

c)
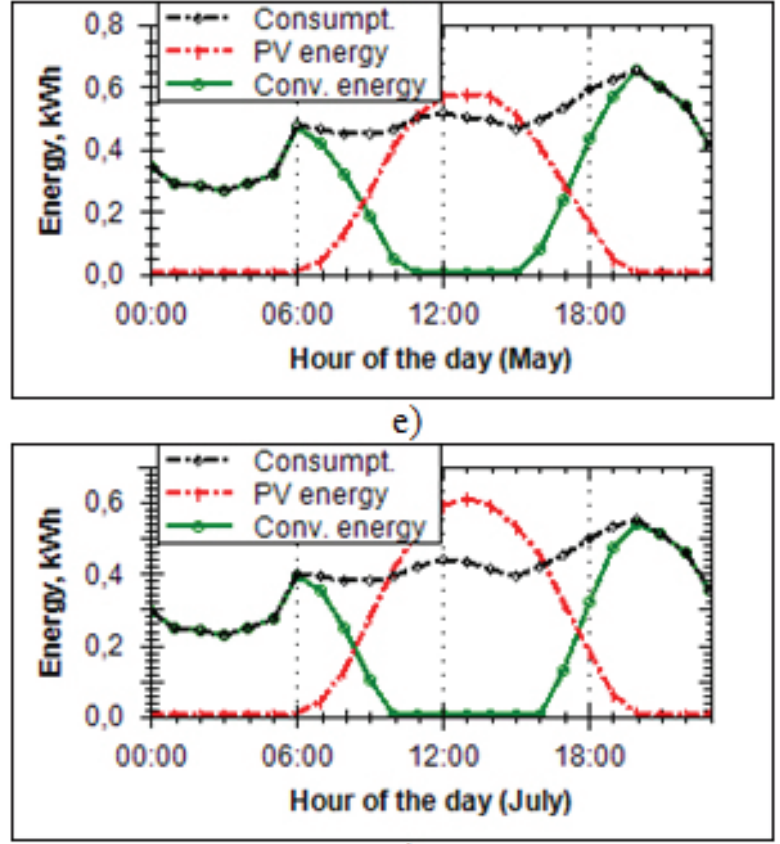

g)

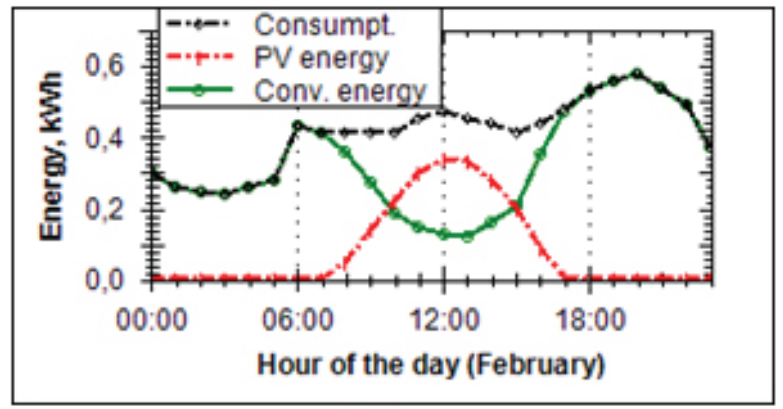

b)

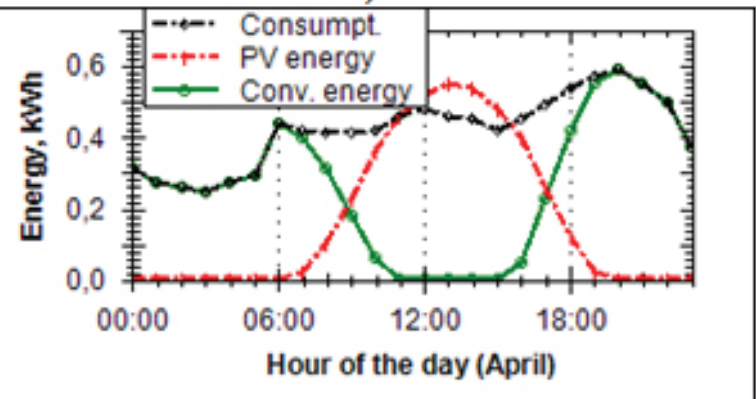

d)
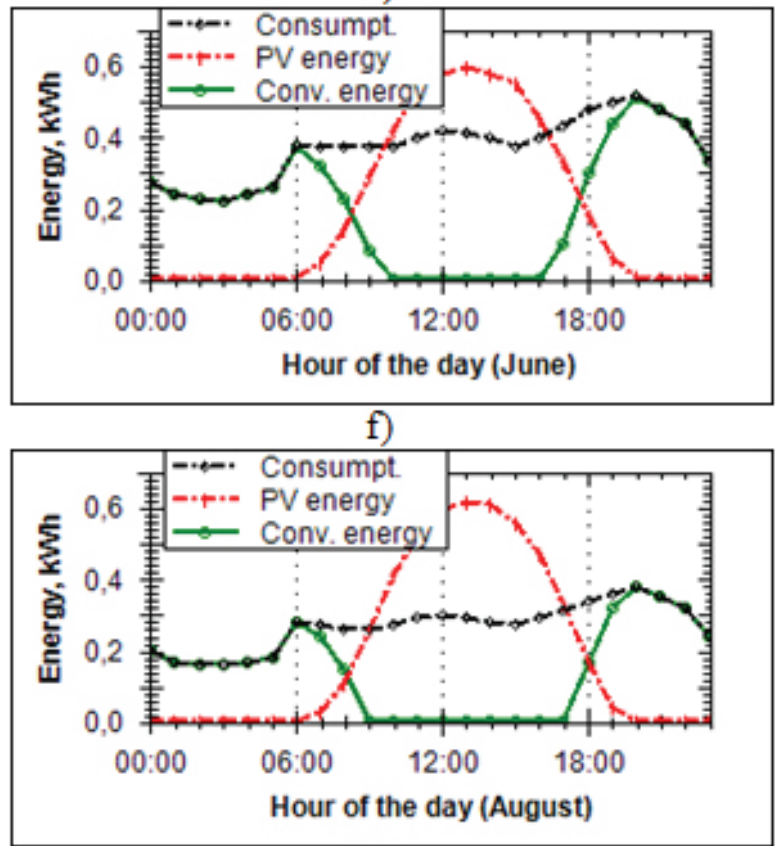

h) 


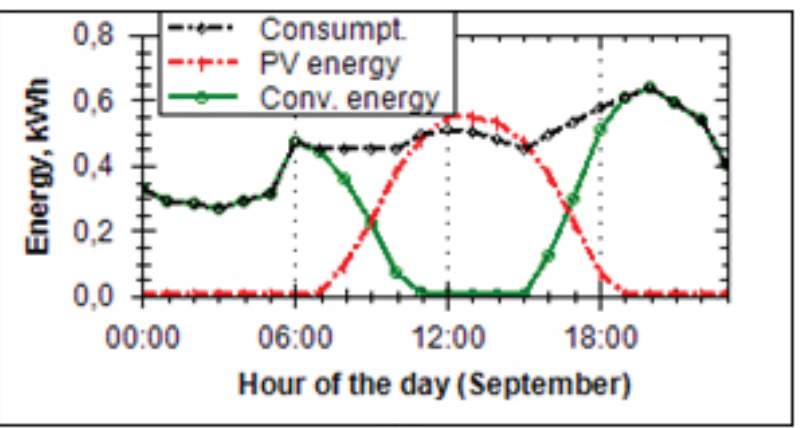

i)

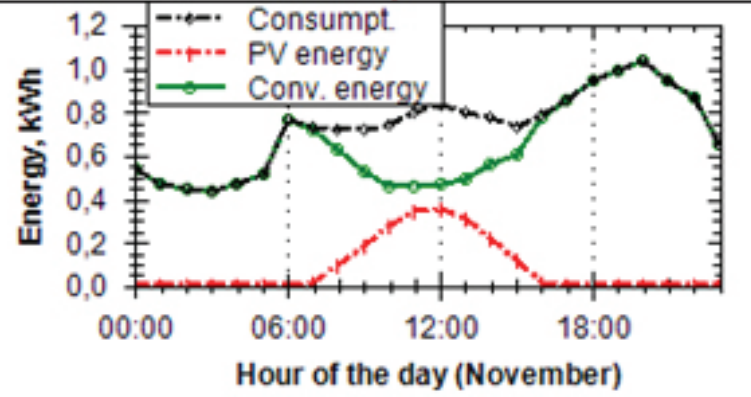

k)

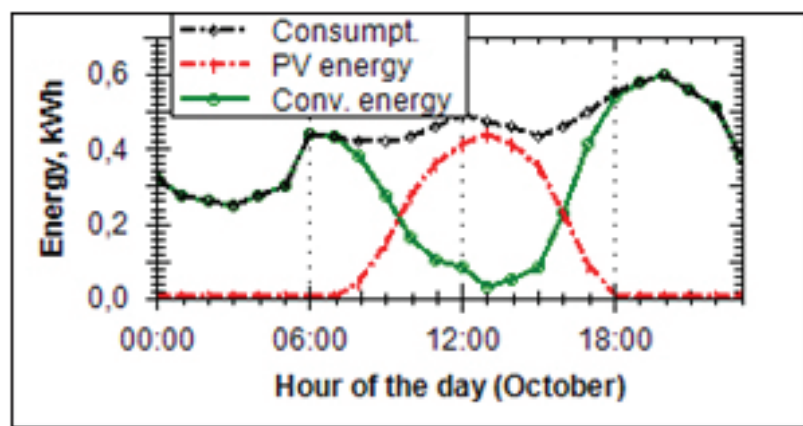

j)

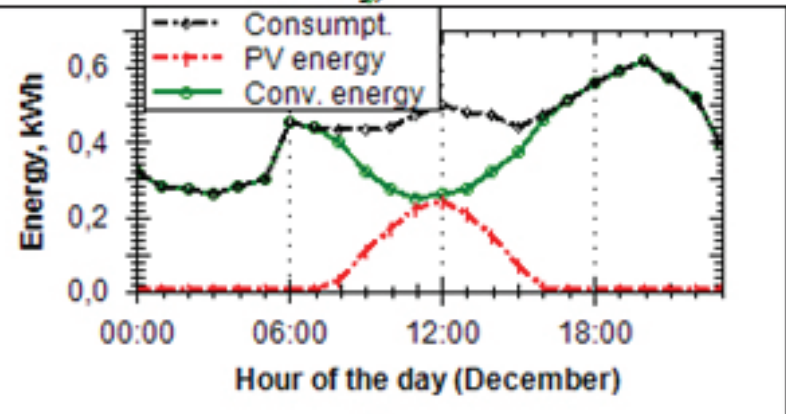

1)

Figure 4: Mean electrical consumption, production and bought conventional energy with Scenario 1 for each month of the year

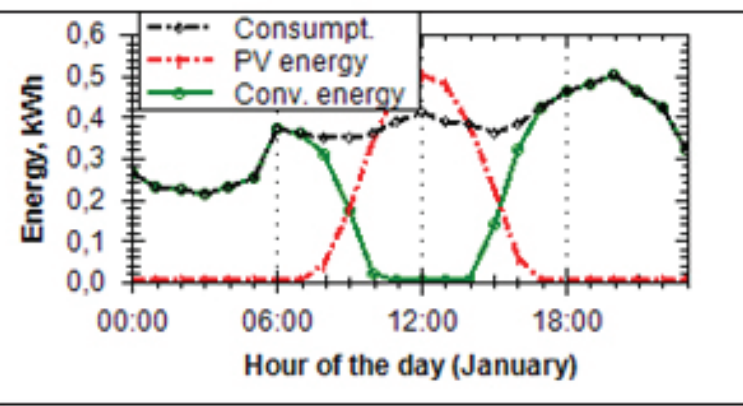

a)

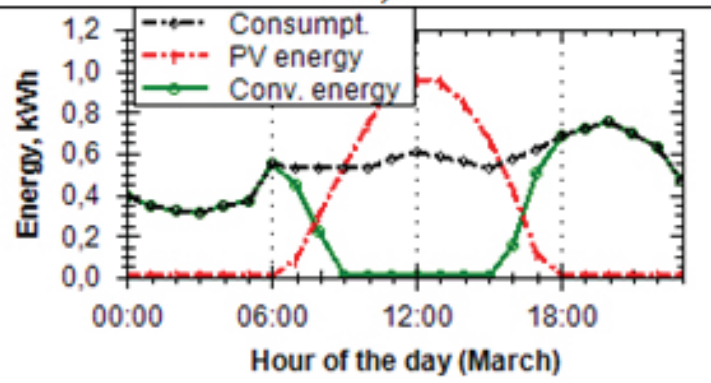

c)

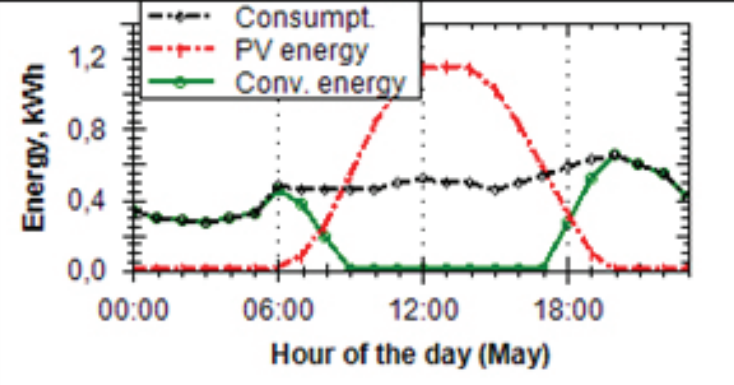

e)

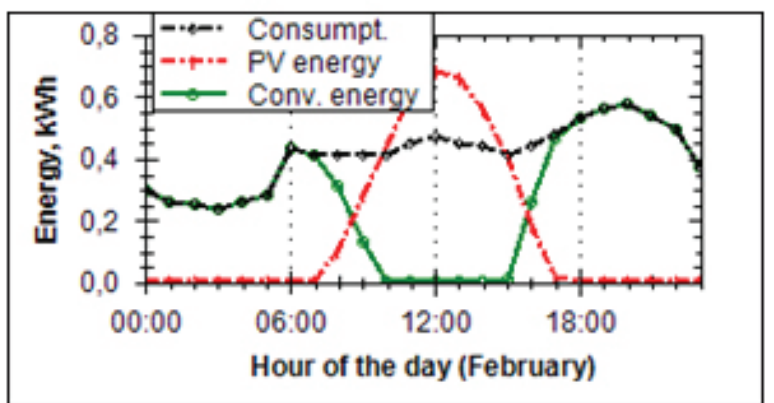

b)

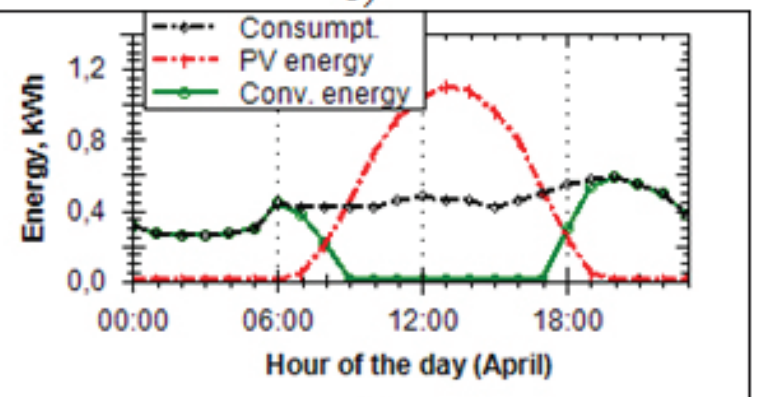

d)

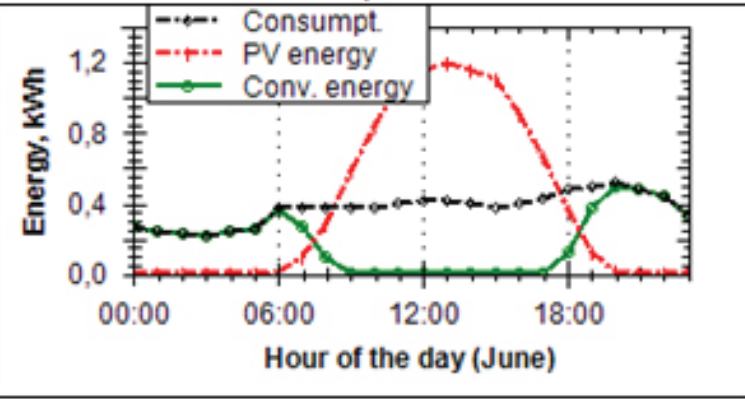

f) 


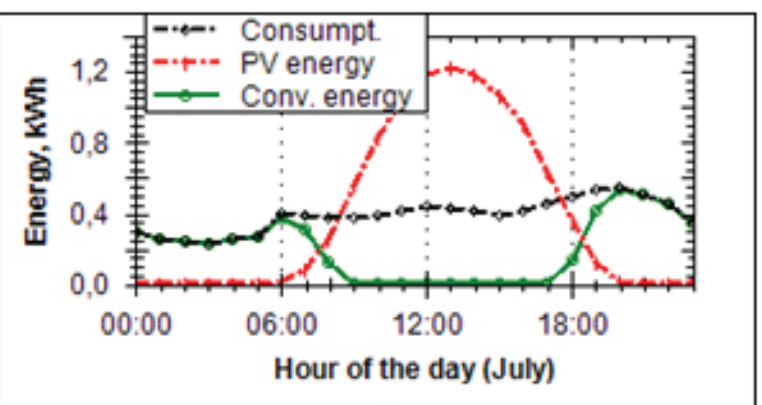

g)
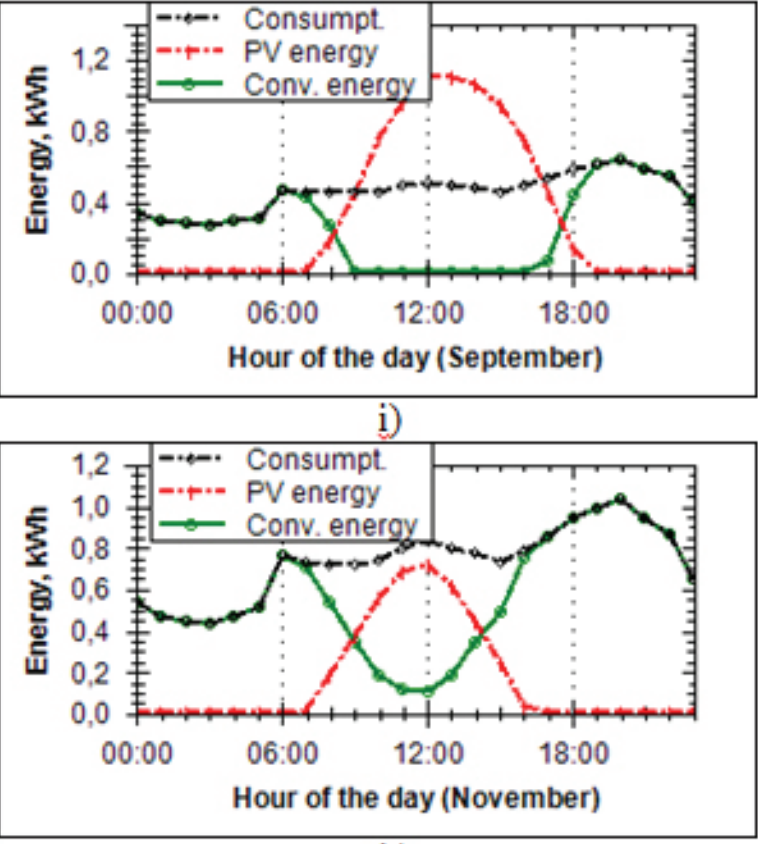

k)

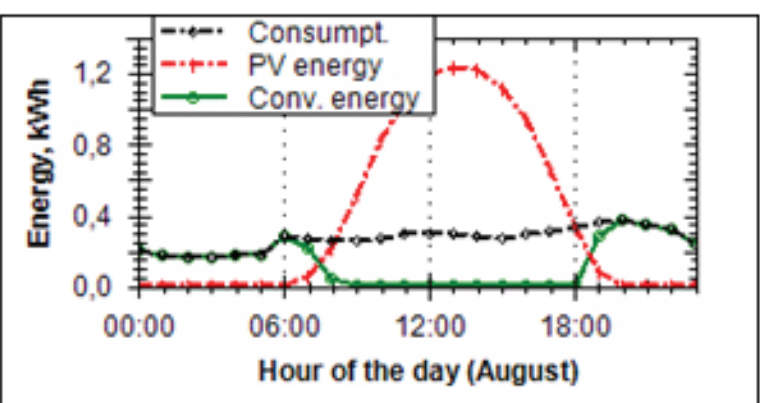

h)
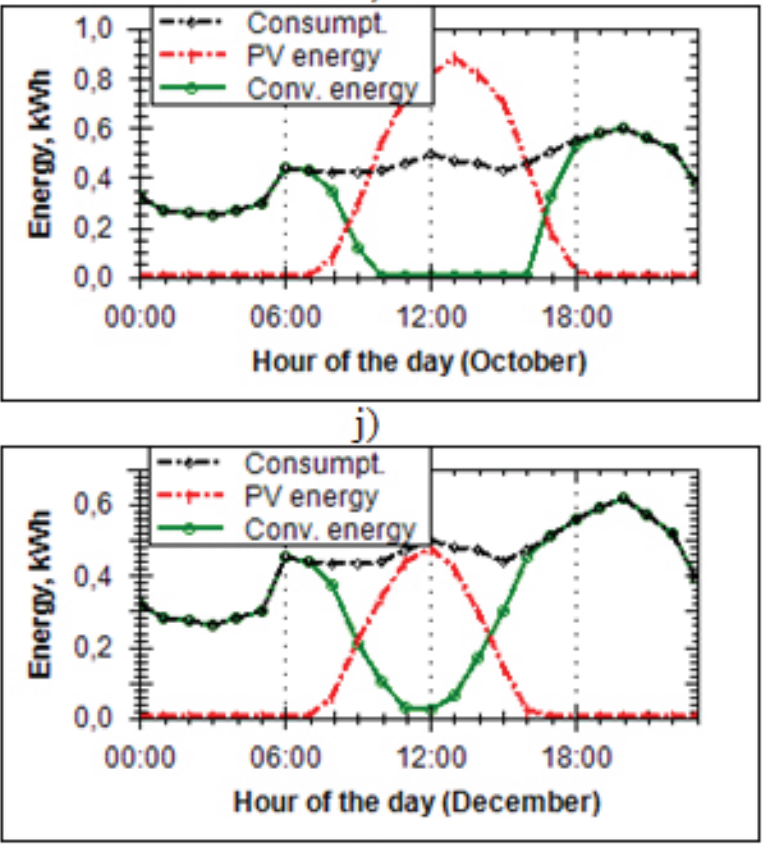

1)

Figure 5: Mean electrical consumption, production and bought conventional energy with Scenario 2 for each month of the year

The ratio between consumed and excess PV energy for the two scenarios is presented in Figure 6.

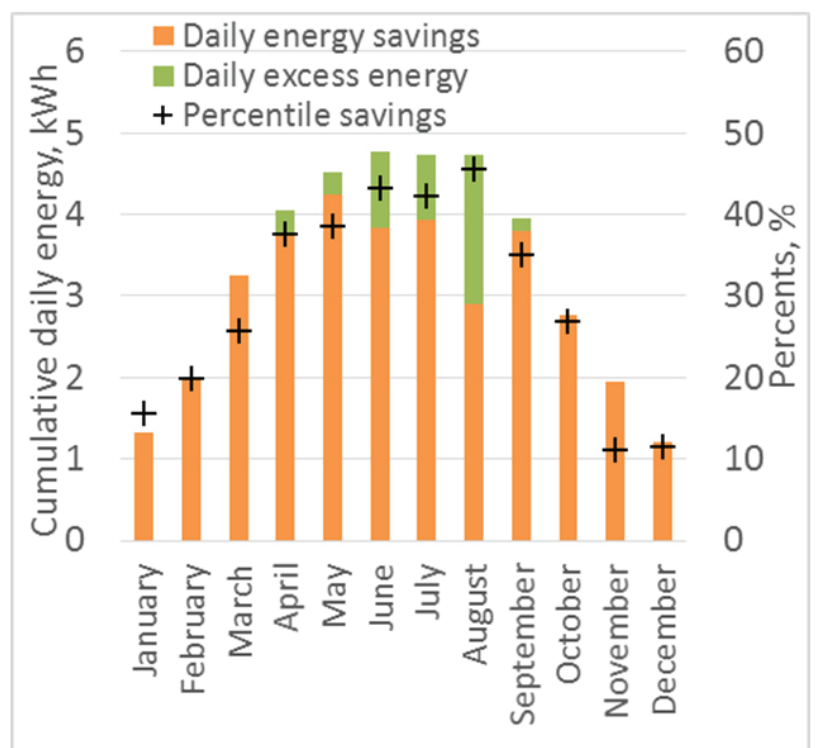

a)

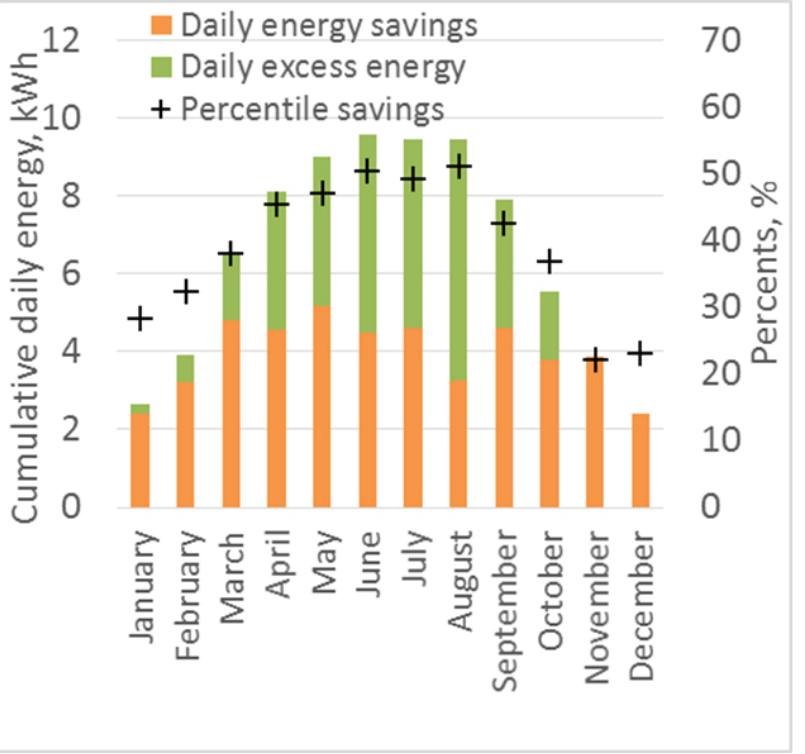

b)

Figure 6: Mean daily consumed PV energy, excess PV energy and percentile energy savings for each month of the year according to: a) Scenario 1; b) Scenario 2 
For Scenario 1 the generated PV energy will generally be lower than the consumption of the apartment during the months January, February, March, October, November and December. In August a lot of excess energy is expected which could be explained with the lower energy consumption due to the holiday season as well as lower cloudiness during this month. For the rest of the months there will be av-erage excess energy.

For Scenario 2 the peak of the produced energy (on average) will be higher than the consumption for every month of the year except November and December, which is expected to lead to significant amounts of excess energy, especially during the summer months.

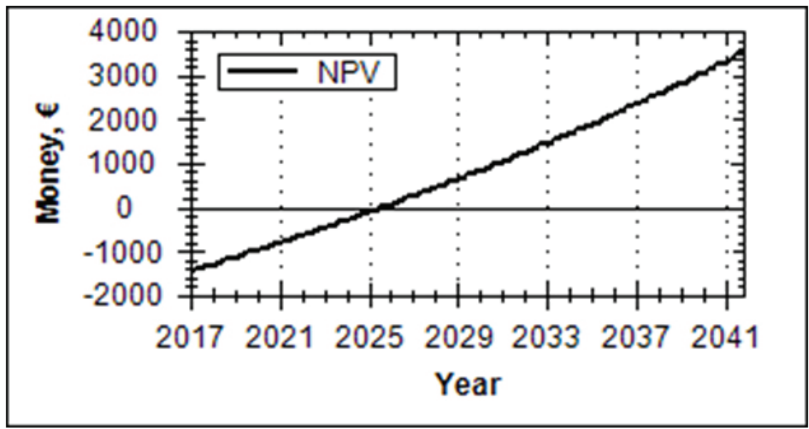

a)

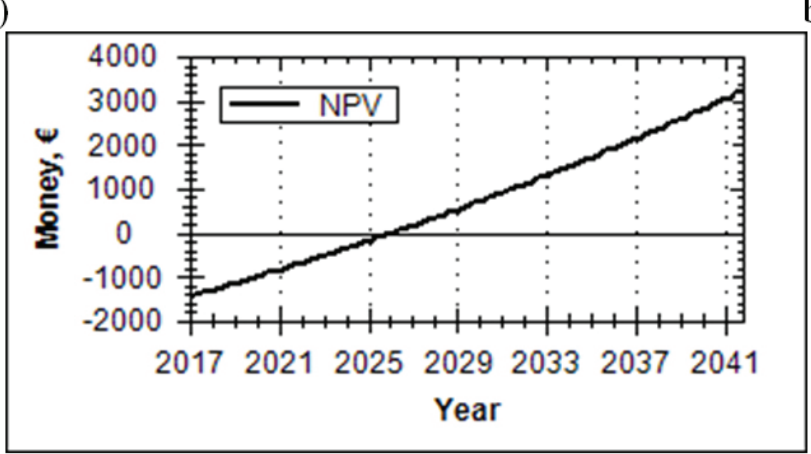

c)

Figure 7: NPV for Scenario 1 with the current prices (a), with price of conventional energy $0.20 € / k W h$ (b) and with buying price of PV energy $0.065 € / k W h(c)$

The results show that the buying price of $\mathrm{PV}$ energy has no significant effect on the investment according to Scenario 1 , which is explained by the low amounts of excess (sold) energy. According to the expectations the increase in the price of the conventional energy could significantly reduce the payback times of the investment.

The initial investment for Scenarios 2 is 3000 $€$ and the ROI with the current prices, with increased conventional energy price $(0.20 € / \mathrm{kWh})$ and with reduced buying price of PV energy $(0.065 € / \mathrm{kWh})$ is $250 \%, 322 \%$ and $199 \%$ respectively. For the three cases the NPV reaches $0 €$ during the 9th year, 7th and 11th year respec-

\section{Benefits from the investment}

The initial investment for Scenarios 1 is $1500 €$ and the performed analysis showed that the ROI with the current prices, with increased conventional energy price $(0.20 € / \mathrm{kWh})$ and with reduced buying price of $\mathrm{PV}$ energy $(0.065 € / \mathrm{kWh})$ is 256 $\%, 361 \%$ and $242 \%$ respectively. In the first case the NPV reaches $0 €$ during the 8th year, in the second case during the 6th year and in the third case during the 9th year. The NPV values at the end of the 25 years period are respectively 3481 $€, 5563 €$ and $3217 €$ (Figure 7 ).

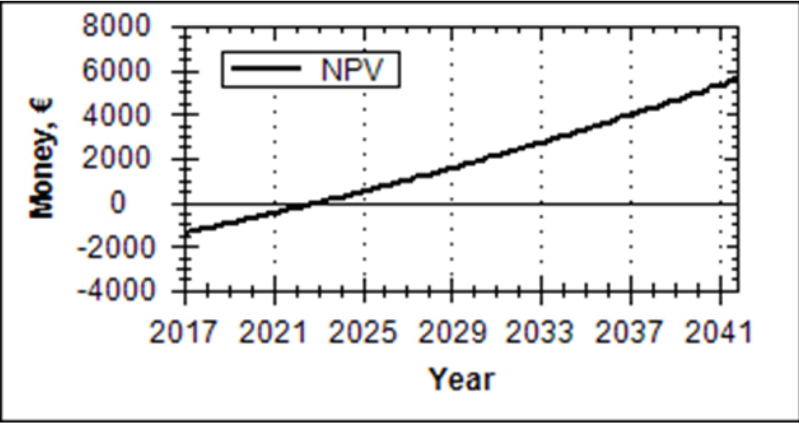

b)$$
\text { . }
$$

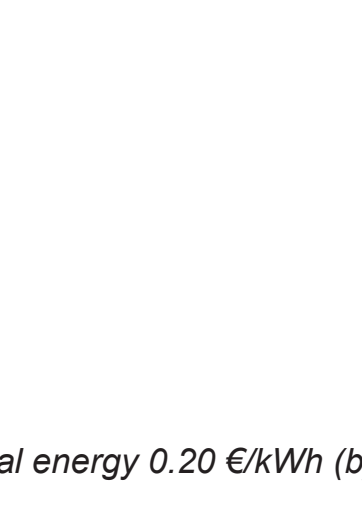

tively, and the price at the end of the 25 year period reaches $6738 €, 9515 €$ and $4723 €$ respectively (Figure 8).

In this situation the increased amount of excess energy makes the buying price of PV energy an important risk factor, which could significantly influence the payback of the investment.

The ecological effect from the investment according to Scenario 1 and 2 have been estimated re-spectively as 0.93 t CO2 and 1.13 t CO2 annually. If corresponding legislation is implemented in Bulgar-ia, these savings could be an additional form of income, however at the time being there are no such op-tions. 


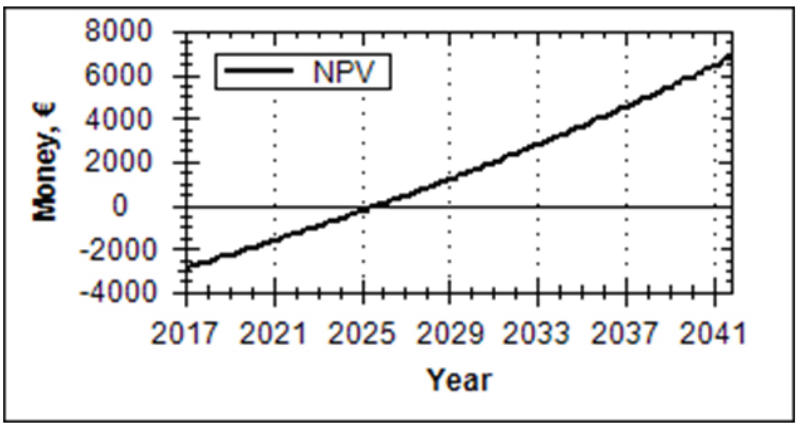

a)

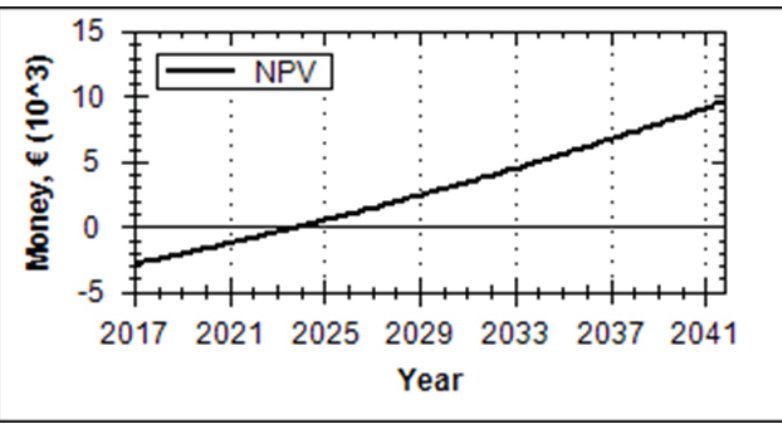

b)

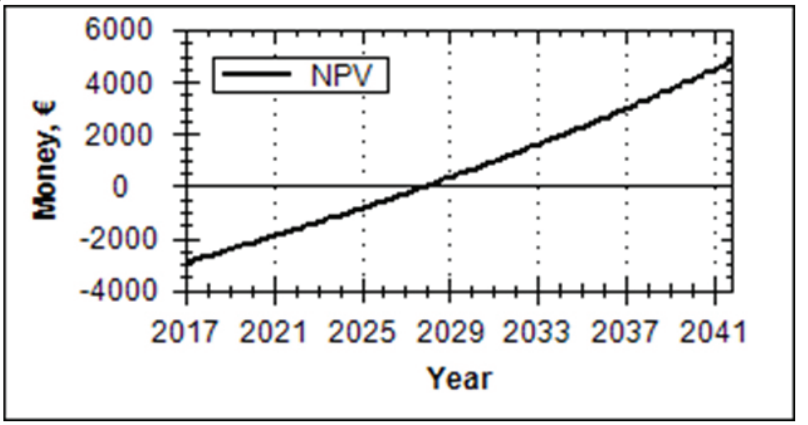

c)

Figure 8: NPV for Scenario 2 with the current prices (a), with price of conventional energy $0.20 € / k W h$ (b) and with buying price of PV energy $0.065 € / \mathrm{kWh}$ (c)

The percentile $\mathrm{CO} 2$ reductions for the two scenarios according to Equation (14) are $35.3 \%$ and $42.3 \%$ respectively, which is a significant reduction, considering only the consumed PV energy is ac-counted in the equation.

\section{CONCLUSION}

In the present study a cost-benefit analysis has been performed on a PV system investment in a common apartment or a small house. The analysis was performed using experimental data for one year period, including the mean daily energy consumption for each month of the year and the mean hourly en-ergy production from $1 \mathrm{~kW}$ installed power in the city of Ruse (Bulgaria) for the different months of the year.

Next the benefits of two types of investment were estimated for $1 \mathrm{kWp}$ and $2 \mathrm{kWp}$ PV power-plant. In the first scenario some amounts of excess energy were available during the summer months, while in the second there is a significant excess energy. If the current prices of energy in Bulgaria are used, in both cases the investment will pay back on the $8^{\text {th }}$ to $9^{\text {th }}$ year and the ROI will be around $250 \%$.

Two risk factors were analysed. The increase in the price of conventional energy has slightly higher impact on the first scenario. The decrease in the buying price of PV energy on the other hand significantly increases the payback period for the second scenario and has little impact on the first scenario. Considering the enormous amount of installed PV power in Bulgaria, the buying price of $\mathrm{PV}$ energy is expected to further drop in the near future. That is why the risk for the investment financial benefits could be lowered if the $\mathrm{PV}$ plant is well sized so that it doesn't generate a lot of excess energy.

Another benefit from the investment are the saved CO2 emissions, which are approximately $1 \mathrm{t} \mathrm{CO} 2$ annually for both scenarios. This could be an additional form of income if appropriate legislation is introduced. The obtained results show that promoting PV sources for own needs in residential houses could be a viable solution for reducing the conventional energy consumption in Bulgaria and decrease the energy dependency.

\section{REFERENCES}

1) Covenant of Mayors, (2010). Technical annex to the SEAP template instructions document: The emis-sion factors.

2) El-Shafy, N. (2009). An Optimum Control Strategy for Energy Management in a Remote Area Stand-Alone PV System. The Open Renewable Energy Journal, 2, 91-98. 
3) Elhassan, Z. A. M., Zain, M. F. M., Sopian, K., Abass, A. A. (2012). Design and performance of pho-tovoltaic power system as a renewable energy source for residential in Khartoum. International Journal of the Physical Sciences, 7 (25), 4036-4042.

4) Ghaemi, S., Brauner, G. (2009). User behavior and patterns of electricity use for energy saving. Internationale Energiewirtschaftstagung an der TU Wien, IEWT (2009).

5) Kolhe, M., Kolhe, S., Joshi, J. C. (2002). Economic Viability of Stand-alone Solar Photovoltaic System in Comparison with Dieselpowered System for India. J. Energy Economics, 24 (2):155-165.

6) Manohar, K., Ramkissoon, R., Adeyanju, A. (2015). Cost Benefit Analysis of Implementing a Solar Photovoltaic System. International Journal of Innovative Research in Science, Engineering and Technol-ogy, 4 (12), 1-8.

7) Ministry of the Environment and Water. (2014). Estimation and forecast of the emission factor of greenhouse gases for the national electrical network of Bulgaria for the period 2014-2020 (In Bulgarian), Sofia, Bulgaria.http://www5.moew.government. bg/wp-content/uploads/file/Climate/Climate Change_Policy_Directorate/IECCP/AKTUALNO/Bulgaria_EGEF_2014.pdf

8) Paateron, J., Lund, P. (2005). A model for generating household electricity load profiles. Int. J. Energy Res, 30, 273-290.
9) Ranabhat, K, Patrikeev, L., Revina, A.A., Adrianov, K., Sofronova, E. (2016). An introduction to solar cell technology. Journal of Applied Engineering Science, 14 (4), 405, 481-491.

10) Ziuku S., Meyer, E. (2012). Economic viability of a residential building integrated photovoltaic gen-erator in South Africa. International Journal of Energy And Environment, 3 (6), 905-914.

11) https://www.sunnyportal.com, retrieved on February 1st, 2017.

12) http://www.nrel.gov/analysis/tech_cost_om_ dg.html, retrieved on February $1^{\text {st }}, 2017$.

13) http://www.motto-engineering.com/bg/produkti/solarni-sistemi/mrezhovi-solarni-sistemi/mrejova-fotovoltaichna-sistema-3kwp-153-detail, retrieved on February 1st, 2017.

14)http://ecosolar-bg.com/мрежовифотоволтаични-централи, retrieved on February $1^{\text {st }}, 2017$.

15) https://www.energo-pro.bg/bg/Dejstvashticeni-na-elektroenergiyata-Bitovi-klienti, retrieved on Feb-ruary 1 ${ }^{\text {st }}, 2017$.

Paper sent to revision: 02.04.2016.

Paper ready for publication: 05.02.2017. 